\title{
High Benthic Turnover Rates in Buried Sediments of Deep-Sea Trenches
}

\author{
MATTHIAS ZABEL ${ }^{1}$, RONNIE N GLUD ${ }^{2}$, HAMED SANEI ${ }^{3}$, \\ MARCUS ELVERT ${ }^{1}$, PEI-CHUAN CHUANG ${ }^{4}$, EMANUEL \\ OKUMA $^{1}$ AND MARTIN KÖLLING ${ }^{1}$ \\ ${ }^{1}$ University of Bremen \\ ${ }^{2}$ University of Southern Denmark \\ ${ }^{3}$ Aarhus University \\ ${ }^{4}$ GEOMAR \\ Presenting Author: mzabel@uni-bremen.de
}

Sediments from abyssal plains and in deep-sea trenches have long been considered relatively inactive from a microbiological perspective. High abundances of benthic organisms (Danovaro et al. 2003) and high microbial carbon turnover rates at the seafloor surface (Glud et al. 2013) have already corrected this assumption for some deep-sea trenches. Apparently, partial ocean trenches act as a trap for particulate organic matter transported by currents, debris flows, and mass waste deposits from the steep margins into the trenches. Biogeochemical studies in deep-sea trenches have existed only for surface sediments. Here we present the first pore water and solid phase results from deeply buried sediments from the Atacama and Japan Trenches. The results show that microbial activity even at several meters below the seafloor can reach comparable intensities as that in the organic-rich sediments in the high-production areas of coastal upwelling regions. Despite significantly lower total organic carbon contents in the sediments of the trenches, considerable flux rates were observed. We attribute this to the specific sediment dynamic in trench systems. The sediments are characterized by a large number of turbidites, which contribute to the high accumulation rates observed in the sediments. Naturally, higher flux of reactive, highly degradable organic matter is buried relatively quickly in the deeper sediments that feed anaerobic bacterial activity. These first pore water investigations on deep sediments from two deep-sea trenches provide new insights to our understanding of the benthic turnover in the hadal zones.

Danovaro et al. (2003) Deep-Sea Research I 50, 1411-1420.

Glud et al. (2013) Nature Geoscience 6, 284-288. 